\title{
PENERAPAN MODEL PEMBELAJARAN KOOPERATIF TIPE STUDENT TEAMS ACHIEVEMENT DIVISION (STAD) UNTUK MENINGKATKAN KEMAMPUAN MENULIS PARAGRAF EKSPOSISI SISWA KELAS VIII SMP MUTIARA SINGARAJA
}

\author{
IGA Artha Prihaniwati ${ }^{1}$, I Md Sutama², IA Md Darmayanti ${ }^{3}$ \\ Jurusan Pendidikan Bahasa dan Sastra Indonesia \\ Universitas Pendidikan Ganesha \\ Singaraja, Indonesia \\ e-mail:\{artaprihaniwati@gmail.com, imadesutamaubd@gmail.com, \\ dayudarmayanti1984@yahoo.com\}@undiksha.ac.id
}

\begin{abstract}
ABSTRAK
Penelitian Tindakan Kelas ini bertujuan untuk mengetahui (1) langkah-langkah penerapan model pembelajaran koopertif tipe Student Teams Achievement Division (STAD) untuk meningkatkan kemampuan menulis paragraf eksposisi siswa kelas VIII SMP Mutiara Singaraja, (2) hasil belajar menulis paragraf eksposisi menggunakan model pembelajaran kooperatif tipe Student Teams Achievement Division (STAD) pada kelas VIII SMP Mutiara Singaraja. Penelitian ini merupakan penelitian tindakan kelas. Subjek penelitian ini adalah siswa kelas VIII SMP Mutiara Singaraja dan objek yang dikaji adalah penerapan model pembelajaran STAD untuk meningkatkan kemampuan siswa menulis paragraf eksposisi, dan kemampuan siswa dalam menulis paragraf eksposisi. Metode pengumpulan data yang digunakan adalah metode observasi dan metode tes. Data dianalisis dengan teknik analisis data kualitatif dan kuantitatif. Berdasarkan analisis hasil penelitian yang telah dilakukan, ditemukan dua hal berikut, (1) Langkah-langkah penerapan model pembelajaran kooperatif tipe STAD dalam menulis paragraf eksposisi adalah siswa dibagi menjadi beberapa kelompok heterogen, setiap kelompok menentukan satu tema bebas untuk dikembangkan, perwakilan kelompok mempresentasikan pekerjaannya, siswa kembali ke bangku masing-masinguntukmenerima tes. (2) Hasil belajar siswa dengan menggunakan model pembelajaran kooperatif tipe STAD terbukti dapat meningkat. Skor ratarata siswa pratindakan adalah 69,77 . Pada siklus I, skor meningkat menjadi 77,41 , dan meningkat lagi pada siklus II menjadi 83,90. Oleh karena itu, peneliti menyarankan agar model pembelajaran ini dapat diterapkan oleh guru bahasa Indonesia untuk meningkatkan kemampuan menulis paragraf eksposisi siswa.
\end{abstract}

Kata Kunci:pembelajaran kooperatif, STAD, meningkatkan, eksposisi

\begin{abstract}
The aim of research action class is (1) to know about the steps of cooperative learning type STAD to improve the student skill in writing exposition paragraph at VIII grades of SMP Mutiara Singaraja. (2) the learning outcomes of this writing skill in exposition paragraph use learning cooperative type STAD at VIII grades of SMP Mutiara Singaraja. This research is research action class. The subject of this research is students at VIII grade of SMP Mutiara Singaraja and the object implemented strategy type STAD to improve student skill in writing exposition paragraph. The method 1 of collecting data which which is used are observation and test methods. The data analysis technique of quantitatif and qualiaif. Based on e learnin oucomes $f$ e daa analsis wic is done (1) the steps of the implementation learning cooperative type STAD in writing exposition paragraph is the students dividied info severval heterogen groups, later on each groups determine the theme, after presented, the students back to their own sit,.at least determine gives the test to know about the students outcomes.The students outcommes in stad. (2) the result of the students learning type STAD is improve the students writing exposition paragraph. The average score of
\end{abstract}


the students in preaction is 66,77 . On the 1 st siklus increase to 77,41 and 83,90 on the 2 nd siklus. This research may implemented in the classroom by the teacher the improve students writing exposition.

Keywords: learningcooperative, STAD, improving, exposition

\section{PENDAHULUAN}

Bahasa memegang peran penting dalam kegiatan berkomunikasi manusia. Peranan bahasa sangat penting sebab bahasa adalah alat komunikasi, menarik perhatian, untuk membentuk, serta mengembangkan nilai-nilai kehidupan. Menurut Sabarti (1993: 2), bahasa merupakan sarana utama untuk berpikir dan bernalar. Manusia berpikir tidak hanya dengan otaknya, dengan bahasa manusia menyampaikam hasil pemikiran atau penalaran, sikap serta perasaannya. Bahasa memiliki peran sentral dalam perkembangan intelektual, sosial, dan emosional manusia serta menjadi penunjang keberhasilan dalam mempelajari segala bidang kehidupan baik di sekolah maupun dalam bermasyarakat. Pengajaran bahasa dan sastra Indonesia berfungsi sebagai sarana untuk meningkatkan pengetahuan dan keterampilan berbahasa Indonesia dalam rangka pelestarian dan pengembangan budaya. Bahasa tersebut berupa rangkaian bunyi, tanda, atau lambang yang dikeluarkan melalui alat ucap manusia untuk menyampaikan isi hatinya kepada manusia lain (Widodo, 1994: 1).

Keterampilan berbahasa dalam pembelajaran bahasa Indonesia dibagi menjadi empat aspek yaitu menyimak, berbicara, membaca, dan menulis. Keempat aspek tersebut berkaitan dan saling mendukung dalam penyelenggaraan belajar-mengajar di kelas. Keterampilan menyimak digunakan dalam menangkap dan mengumpulkan informasi serta gagasan dari siswa. Keterampilan berbicara digunakan dalam menyampaikan materi, memberi pertanyaan dalam mengelola kelas. Keterampilan membaca digunakan dalam memahami dan menangkap isi pesan secara tertulis sementara keterampilan menulis digunakan menyampaikan pesan secara tertulis, seperti menjelaskan materi secara tertulis ataupun dalam memberikan evaluasi (Balitbang, 2002: 65).
Keterampilan menulis sangat penting dikuasai oleh siswa dalam pengajaran bahasa Indonesia di sekolah. Hal ini disebabkan oleh menulis merupakan pengetahuan yang mendasari seluruh kegiatan dalam pendidikan. Dengan kata lain, pengajaran menulis merupakan muara dari seluruh aspek keterampilan berbahasa. Santana (2007:2) menyatakan,

Menulis itu pekerjaan penting. Tidak ada seseorang yang tidak melakukan pekerjaan menulis. Mulai dari menulis diary kejadian, mencatat omongan guru atau dosen, sampai dengan menjawab ujian, contohnya. Yang menulisdengan baik, dia berarti punya sesuatu sebut saja kapasitas. la memiliki kelebihan catat mencatat yang orang lain tidak tahu. la dapat bersenda gurau dengan alat tulis dan seperangkat ide, yang dituangkan ke dalam gaya penyajian tertentu. Keberhasilan siswa dalam mengikuti pelajaran di sekolah sering ditentukan oleh keterampilan menulis. Selain dapat memudahkan siswa berpikir secara kritis, menulis juga dapat membantu siswa dalam mengomunikasikan perasaan, pendapat, dan pengalaman pada orang lain.

Menulis bukan hanya menghasilkan tulisan semata, melainkan suatu tindakan aktif yang dihasilkan dari hasil curahan pikiran yang mengandung makna yang dihasilkan dan mudah dipahami orang lain (pembaca).

Ariasih (dalam Pasek 2001:85) menyatakan bahwa dengan keterampilan menulis seseorang dapat merekam, melaporkan, memberitahukan dan meyakinkan orang lain.Menulis adalah kegiatan mengembangkan pikiran dalam bentuk tulisan. Selain itu, menulis dan mengarang dapat juga dikatakan sebagai seni mengekspresikan ide atau perasaan melalui tulisan. Akhadiah (dalam Dedy Pramana Putra, 2013: 2) menyatakan menulis memiliki beberapa keuntungan. Pertama, dengan menulis, kita dapat lebih mengenali kemampuan dan potensi diri kita. Kedua, melalui kegiatan menulis kita dapat 
banyak menyerap, mencari serta menguasai informasi sehubungan dengan topik yang kita tulis. Ketiga, menulis mengajarkan kita berpikir kritis sehingga mampu mengorganisasikan gagasan secara sistematis. Di zaman yang modern ini, kemampuan menulis dapat meningkatkan taraf hidup. Untuk itu, harus dilakukan pembinaan yang intensif terhadap kemampuan menulis dengan tidak mengabaikan aspek bahasa lain. Hal itu sesuai dengan yang dikatakan Tarigan (1982: 1), bahwa keterampilan menulis bersifat fungsional terhadap pengembangan diri siswa, baik untuk studi maupun untuk bermasyarakat. Keterampilan menulis tidak serta merta datang dan dapat dikuasai. Dibutuhkan proses yang berkesinambungan agar seseorang dapat menguasainya. Keterampilan ini dikatakan demikian karena dalam penerapannya melibatkan keterampilan berbahasa lain, yaitu keterampilan membaca. Menurut Azies dan Alwiasiah (1996: 128), keterampilan menulis erat kaitannya dengan membaca. Hubungan itu mengarah terhadap hubungan saling memengaruhi dan melengkapi satu sama lainnya. Seseorang akan lebih mudah menulis apabila rajin membaca. Kebiasaan menulis tidak terlaksana tanpa kebiasaan membaca. Kebiasaan membaca dapat memperluas pengetahuan, wawasan, dan kosakata. Selain berhubungan dengan membaca, keterampilan menulis merupakan keterampilan yang membutuhkan penguasaan bahasa yang baik. Dengan kata lain, kegiatan membaca merupakan dasar dari kegiatan menulis.

Dalam kehidupan modern ini, jelas bahwa keterampilan menulis sangat dibutuhkan. Seperti yang sudah berjalan sampai saat ini, banyak orang yang berpendapat keterampilan menulis itu merupakan suatu ciri orang yang terpelajar atau bangsa yang terpelajar. Jika sudah memiliki kemampuan menulis tentu akan dapat mengusulkan pendapatnya tentang suatu kejadian bagi khalayak ramai. Sehubungan dengan itu, Morsey (dalam Tarigan, 1994: 4) mengatakan bahwa menulis dipergunakan oleh orang terpelajar untuk mencatat, merekam, meyakinkan, melaporkan, memberitahukan, dan memengaruhi serta tujuan seperti itu hanya dapat dicapai dengan baik oleh orangorang yang dapat menyusun pikirannya dan mengutarakannya dengan jelas. Dengan demikian, sudah jelas bahwa menulis sangat penting diajarkan pada siswa.

Terdapat empat cara orang menuturkan sesuatu, yaitu bercerita, memaparkan, melukiskan, membincangkan dan mengajak. Keempat bentuk tersebut dapat diwujudkan ke dalam bentuk tulisan. Dengan demikian, dapat dikatakan bahwa tulisan dapat dibagi menjadi lima bentuk, yaitu narasi(cerita), deskripsi (lukisan), eksposisi (pemaparan), argumentasi(bincangan), dan persuasi(mengajak). Namun, pada penelitian ini, penulis akan memfokuskan pada salah satu bentuk tulisan saja, yaitu eksposisi (pemaparan).

Paragraf eksposisi merupakan tulisan yang menjelaskan proses terjadinya sesuatu.Suparno (dalam Ni Kadek Rusmini, 2013: 22) mengungkapkan bahwa paragraf eksposisi merupakan tulisan yang bertujuan utama memberitahu, mengupas, menguraikan atau menerangkan sesuatu. Menurut Gie (1995:56) paragraf eksposisi merupakan suatu bentuk pengungkapan yang menyajikan fakta-fakta secara teratur, logis dan terpadu bertujuan memberikan penjelasan kepada pembaca mengenai suatu ide, persoalan, proses, atau peralatan. Ahli lain (Keraf, 1997: 86) menyatakan bahwa eksposisi adalah tulisan yang isinya bertujuan memperluas pengetahuan pembaca. Pada intinya, ahli-ahli tersebut memiliki pandangan bahwa eksposisi merupakan suatu tulisan yang bertujuan memaparkan sesuatu untuk menambah pengetahuan pembaca. Oleh karena itu, kemampuan menulis eksposisi sangat perlu diajarkan karena dalam pengajaran menulis, selain siswa mampu mengungkapkan ide untuk menceritakan, menggambarkan, mengajak, meyakinkan, dan mengungkapkan pendapat lewat tulisan, siswa juga diharapkan mampu menerangkan sesuatu sehingga dapat menambah pengetahuan pembaca. 
Berdasarkan observasi awal di SMP Mutiara Singaraja, nilai rata-rata menulis paragraf eksposisi siswa di bawah 70, sedangkan kriteria ketuntasan minimal (KKM) yang ditetapkan sekolah adalah 78. Rendahnya kemampuan siswa dalam menulis, dipengaruhi oleh 1) adanya kesulitan dalam menulis, 2) kurangnya keinginan siswa untuk belajar dan 3) proses belajar yang kurang menarik. Mengacu pada permasalahan inilah peran seorang guru sangatlah penting di dalam menerapkan model pembelajaran yang tepat sehingga, memacu siswa berperan aktifterhadap materi yang diberikan, khususnya dalam menulis paragraf eksposisi. Oleh karena itu peneliti merasa terdorong untuk melakukan penelitian dengan mencoba menerapkan model pembelajaran kooperatif tipe Student Teams Achievement Division (STAD) untuk meningkatkan kemampuan menulis paragraf eksposisi siswa kelas VIII SMP Mutiara Singaraja.

Pembelajaran kooperatif (cooperative learning) sejatinya sesuai dengan fitrah manusia sebagai makhluk sosial yang penuh ketergantungan dengan orang lain, mempunyai tujuan dan tanggung jawab bersama, serta pembagian tugas dan rasa senasib. Dengan memanfaatkan kenyataan itu, belajar berkelompok secara kooperatif, siswa dilatih dan dibiasakan untuk saling berbagi (sharing) pengetahuan, pengalaman, tugas, danbertanggug jawab. Metode kooperatif ini merupakan pembelajaran yang menekankan belajar dalam kelompok heterogen saling membantu satu sama lain, bekerjasama menyelesaikan masalah dan menyatukan pendapat untuk memperoleh keberhasilan yang optimal baik kelompok maupun individual.

Pembelajaran kooperatif tipe Student Teams Achievement Division (STAD) merupakan tipe yang dikembangkan oleh Slavin. Ini merupakan salah satu tipe kooperatif yang menekankan pada adanya aktivitas dan interaksi di antara siswa untuk saling memotivasi dan saling membantu dalam menguasai materi pelajaran guna mencapai prestasi yang maksimal (Isjoni, 2009:51). Menurut Slavin (2009:143), tipe
STAD merupakan salah satu metode pembelajaran kooperatif yang paling sederhana dan merupakan model yang paling baik untuk pemulaan bagi para guru yang baru menggunakan pendekatan kooperatif. Pembelajaran kooperatif dapat meningkatkan hasil belajar, hubungan antar kelompok, memberi kesempatan kepada siswa berinteraksi dan beradaptasi dengan teman satu tim untuk mencerna materi pelajaran, meningkatkan rasa percaya diri dan motivasi belajar, membina sifat kebersamaan, peduli satu sama lain, dan tenggang rasa, serta mempunyai rasa adil terhadap keberhasilan tim.

Ada beberapa teori yang mendasari sistem bekerja dalam kelompok kooperatif lebih layak daripada belajar di kelas secara tradisional. Motivasi siswa pada pembelajaran kooperatif terutama terletak pada bentuk hadiah/struktur pencapaian tujuan saat siswa melaksanakan kegiatan. Oleh karena itu, untuk mencapai tujuan yang diinginkan, kelompok harus saling membantu satu sama lain untuk keberhasilan kelompoknya dan atau yang lebih penting adalah memberi dorongan atau dukungan pada anggota lain untuk berusaha mencapai tujuan yang maksimal.

Pembelajaran kooperatif yang dilakukan dengan benar akan dapat menimbulkan saling ketergantungan yang positif antar anggota kelompok. Anggota kelompok yang satu membutuhkan anggota kelompok yang lain, sehingga secara otomatis akan terjalin kerjasama yang saling menguntungkan. Slavin (dalam Yuliandayani, 2005: 10)menyebutkan beberapa keunggulan dari model pembelajaran kooperatif tipe STAD, salah satunya adalah memotivasi siswa untuk meningkatkan prestasi belajar dan menciptakan suasana belajar mengajar yang bebas, bergairah dan kondusif. Keunggulan tersebut dapat membantu menanggulangi kekurangan strategi pembelaajaran yang biasa dilaakukan oleh guru dalam pelajaran bahasa Indonesia, khususnya, pada materi menulis paragraf eksposisi.

Sebelum penelitian ini direncanakan, peneliti menemukan hasil penelitian lain terkait model pembelajaran. Penelitian 
pertama dilakukan oleh $\mathrm{Ni}$ Ketut Ari Puspitawati tahun 2013 dengan judul "Penerapan Model Pembelajaran Students Teams Achievement Division (STAD) dengan Media Autentik untuk Meningkatkan Kemampuan Menulis Berita pada Siswa Kelas VIIIB SMP Negeri 1 Kubutambahan".

Penelitian kedua dilakukan oleh Komang Krisna Kumarawati tahun 2015 dengan judul "Penerapaan Model Pembelajaran Kooperatif Tipe Student Teams Achievement Division (STAD) untuk Meningkatkan Kemampuan Menulis Teks Laporan Hasil Observasi Siswa Kelas X MIA 1 SMAN 1 Mendoyo".

Penelitian ketiga dilakukan oleh Putu Edy Permana Putra tahun 2015 dengan judul "Penerapam Model Pembelajaran Kooperatif Tipe STAD untuk Meningkatkan Kemampuan Siswa Menulis Lengkara dengan Aksara Bali di Kelas X Boga 2 SMK Negeri 1 Seririt Tahun Pelajaran 2014/2015".

Penelitan keempat dilakukan oleh I Nyoman Agus Ardita tahun 2015 dengan judul "Penerapan Model Pembelajaran Kooperatif Tipe STAD (Student Teams Achievement Division) Berbantuan Media Permainan Puzzle untuk Meningkatkan Penguasaan Kosakata Bahasa Jepang pada Siswa Kelas X3 SMK Marya Wisata Singaraja Tahun Ajaran 2014/2015".

Keempat penelitian di atas memiliki persamaan dengan penelitian yang dilakukan peneliti. Persamaan tersebut adalah sama-sama menggunakan model pembelajaran kooperatif tipe Student Teams Achievement Division (STAD). Walaupun ada persamaan antara penelitian di atas dan penelitian yang dilakukan peneliti, tampaknya lebih banyak perbedaannya. Perbedaannya adalah terlihat dari subjek penelitian, lokasi penelitian, dan tentunya rumusan masalah penelitian. Subjek penelitian adalah siswa kelas VIII SMP Mutiara Singaraja. Penelitian yang peneliti lakukan berfokus pada langkah-langkah pembelajaran dan hasil pembelajaran menulis paragraf eksposisi siswa kelas VIII SMP Mutiara Singaraja dengan menerapkan model pembelajaran kooperartif tipe Student Teams Achievement Division (STAD).
Berdasarkan uraian di atas, terdapat pemikiran peneliti untuk menerapkan model pembelajaran kooperatif tipe student teams achievement division (STAD) untuk meningkatkan kemampuan menulis paragraf eksposisi pada mata pelajaran bahasa Indonesia. Selain itu, penelitian ini dilakukan untuk melengkapi sisi lain penelitian-penelitian yang sudah ada. Maka dari itu, diangkatlah penelitian yang berjudul "Penerapan Model Pembelajaran Tipe Student Teams Achievement Division (STAD) untuk Meningkatkan Kemampuan Menulis Paragraf Eksposisi Siswa Kelas VIII SMP Mutiara Singaraja". Penelitian ini diharapkan dapat meningkatkan kemampuan siswa dalam menulis paragraf eksposisi, serta dalam pembelajaran menggunakan model pembelajaran kooperatif tipe STAD ini mampu mendidik siswa untuk berinteraksi dengan siswa lainnya.

\section{METODE PENELITIAN}

Rancangan penelitian yang ada dalam penelitian ini adalah Penelitian Tindakan Kelas (PTK). Dalam penelitian ini mampu (1) menerapkan langkah-langkah model pembelajaran kooperatif tipe STAD,dan (2) mengetahui hasil belajar menulis paragraf eksposisi siswa kelas VIII SMP Mutiara Singaraja. Subjek penelitian ini adalah kelas VIII SMP Mutiara Singaraja karena siswa di kelas inilah yang mengalami masalah dalam kemampuan menulis paragraf eksposisi. Hal tersebut diperoleh dari hasil wawancara yang dilakukan dengan salah seorang guru pengajar bahasa Indonesia kelas VIII yaitu ibu Dra. Ni Luh Putu Arthini bahwa nilai yang diperolah dalam menulis eksposisi siswa kelas VIII masih di bawah KKM.

Objek penelitian ini adalah (1) penerapan model pembelajaran STAD untuk meningkatkan kemampuan siswa menulis paragraf eksposisi, (2) kemampuan siswa dalam menulis paragraf eksposisi.

Metode pengumpulan data dalam penelitian ini meliputi, (1) metode observasi dan, dan (2) metode tes. Metode observasi adalah metode penelitian dengan cara mengadakan pengamatan secara langsung terhadap gejala yang tampak pada objek 
penelitian (Suandi, 2008: 39). Metode observasi, yang digunakan adalah metode observasi kolaboratif. Instrument yang digunakan dalam metode observasi adalah lembar observasi. Metode tes digunakan dengan menggunakan teknik tes esai. Agung, (2014:92) mengatakan bahwa metode tes dalam kaitannya dengan penelitian ialah cara memperoleh data yang berbentuk suatu tugas yang harus dikerjakan oleh seorang atau sekelompok orang yang di tes (testee), dan dari dari tes dapat menghasilkan suatu skor (interval).

Teknik analisis data yang digunakan dalam penelitian ini adalah deskriptif kuantitatif dan deskriptif kualitiatif. Teknik analisis data ini, meliputi dua analisis (1) Analisis Data Langkah-Langkah Pembelajaran. Data yang dikumpulkan mengenai langkah-langkah pembelajaran yang dilakukan dengan metode observasi, dianalisis dengan analisis deskriptif kualitatif. Observasi yang digunakan dalam penelitian ini adalah observasi kolaboratif. Dimana, peneliti tidak hanya mengamati proses pembelajaran saja. Akan tetapi, peneliti juga dapat terlibat langsung dalam kegiatan pembelajaran. Data yang dikumpulkan dengan menggunakan teknik check list. (2) Data tentang hasil belajar apresiasiasi sastra cerpen siswa secara reseptif dianalisis dengan teknik deskriptif kuantitatif. Metode deskriptif kuantitatif menggunakan paparan sederhana yang berkaitan dengan angka-angka. Adapun teknik analisis data menulis paragraf eksposisi siswa dengan menggunakan pedoman penilaian pada setiap pertanyaan di masing-masing indikator. Adapun pedoman penilaiannya dipaparkan sebagai berikut:

Pedoman Penilaian

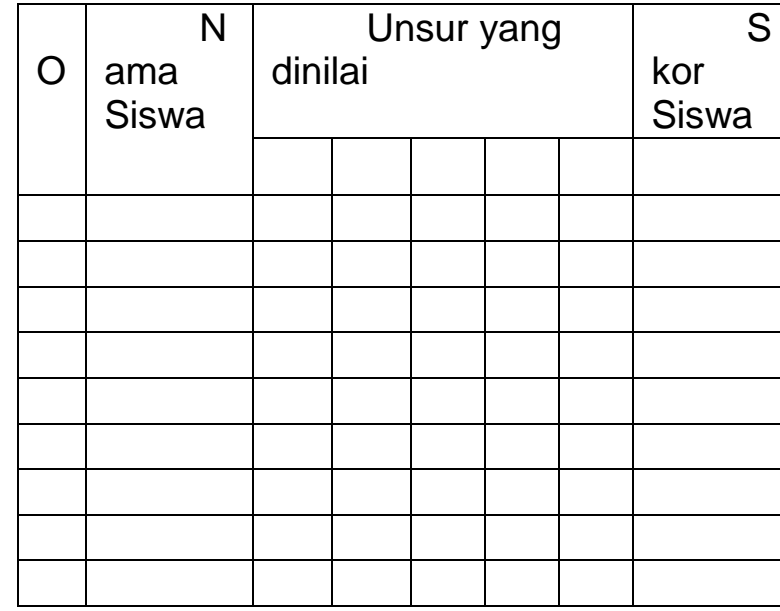

Keterangan:

A: Isi gagasan yang dikemukakan, skor maksimum 35

B: Organisasi isi, skor maksimum 25

C: Tata bahasa, skor maksimum 20

D: Gaya: pilihan struktur dan

kosa kata, skor maksimal 15

E: Ejaan, skor maksimal 5

Secara individual siswa dapat dikatakan baik dalam pembelajaran apresiasi sastra siswa secara reseptif apabila nilai yang diperoleh minimal 76 , karena skor tersebut merupakan krikteria ketuntasan minimal dalam pembelajaran di kelas VIII SMP Mutiara Singaraja.

Secara klasikal pembelajaran dikatakan tuntas apabila $75 \%$ dari jumlah siswa yang ada di kelas tersebut memperoleh nilai minimal 76 , sehingga tindakan dapat dihentikan. Namun, apabila jumlah siswa yang memperoleh nilai 76 kurang dari $75 \%$, maka tindakan perlu mendapat modifikasi, sehingga memperoleh hasil yang diharapkan.

Untuk dapat menetukan ketuntasan individual digunakan rumus sebagai berikut.

$$
\text { Ketuntasan Individu }=\frac{\text { Skor yang diperoleh sisw }}{\text { Skor maksimal }}
$$

Untuk dapat mengetahui presentase siswa yang sudah mencapai ketuntasan dalam belajar, dapat diketahui dengan rumus sebagai berikut.

$$
\text { Ketuntasan klasikal }=\frac{\text { Jumlah siswa yang mempe }}{\text { Jumlah seluruhs }}
$$




\section{HASIL PENELITIAN DAN PEMBAHASAN \\ Hasil Penelitian}

Berdasarkan data awal yang didapat dari guru mata pelajaran bahasa Indonesia di kelas VIII, peneliti dapat menyimpulkan bahwa skor rata-rata kelas VIII belum mencapai KKM yang ditetapkan sekolah yaitu 76. Nilai rata-rata siswa dalam menulis paragraf eksposisi hanya mencapai 69,77. Ketuntasan baru dicapai oleh 15 $(34,09 \%)$ siswa dan sisanya $29(70,73 \%)$ siswa masih tergolong belum tuntas. Nilai tertinggi yang dicapai siswa adalah 80 , sedangkan nilai terendah yang dicapai oleh siswa adalah 50.

Penelitian ini dilaksanakan dalam dua siklus. Setiap siklus menghasilkan data berupa hasil tes yang diberikan di akhir tindakan dan data hasil observasi terhadap penerapan model pembelajaran kooperatif tipe Student Teams Achievement Division (STAD) untuk meningkatkan kemampuan menulis paragraf eksposisi siswa. Data tersebut digunakan untuk menjawab masalah-masalah yang dirumuskan dalam penelitian ini.

Hasil penelitian ini meliputi (1) langkah-langkah pembelajaran dengan menggunakan model pembelajaran kooperatif tipe STAD adalah sebagai berikut. Siswa dibagi menjadi beberapa kelompok heterogen. Setiap kelompok menentukan satu tema bebas untuk dikembangkan menjadi paragraf eksposisi. Setelah paragraf eksposisi tersebut dipresentasikan, siswa kembali ke bangku masing-masing. Terakhir, peneliti mengadakan tes untuk mengetahui hasil belajar siswa.

Berdasarkan observasi yang sudah dilakukan, pada siklus I kegiatan siswa dalam mengikuti proses pembelajaran menjadi lebih baik jika dibandingkan dengan sebelum diterapkan model pembelajaran Student Teams Achievement Division (STAD). Hal ini dapat dibuktikan dengan mengamati peningkatan hasil belajar siswa yang berupa tes. Namun, ada sedikit permasalahan, yakni siswa masih suka bermain-main dan bercanda dengan kelompok pada saat mengerjakan tugas kelompok. Selain itu, siswa juga masih kurang atau belum berani ketika guru meminta siswa untuk menanyakan hal-hal yang terkait dengan pembelajaran. Sementara, pada siklus II hasil observasi terhadap langlah-langkah di kelas sudah lebih baik daripada siklus I. Hal ini dapat dilihat dari keantusiasan siswa dalam mengikuti pembelajaran. Siswa cukup bersemangat ketika kegiatan pembelajaran dilaksanakan, dan juga keributan pada kegiatan diskusi di siklus I sudah mulai berkurang di siklus II. Hal ini terlihat dari tertibnya siswa dalam kegiatan berdiskusi, sehingga mereka menjadi lebih berkonsentrasi dalam menentukan tema maupun menulis paragraf eksposisi. Mereka juga melaksanakan kegiatan pembelajaran secara terstruktur sesuai dengan langkah-langkah pembelajaran yang diarahkan oleh guru.

(2) Hasil belajar siswa dalam menulis paragraf eksposisi sebelum diadakan tindakan adalah 69,77. Skor tersebut masih sangat jauh dari skor KKM yaitu 76.Selanjutnya, pada tindakan siklus siklus I skor rata-rata siswa meningkat menjadi 77,41 . Dari 41 orang siswa yang mengikuti tes, siswa yang berkategori amat baik sebanyak $3(7,31 \%)$ orang, siswa dengan kategori baik sebanyak $12(29,26 \%)$ orang, siswa dengan kategori cukup sebanyak 15 $(36,58 \%)$, siswa dengan kategori kurang 5 $(12,19 \%)$ orang, dan siswa dengan kategori sangat kurang sebanyak $4(9,75)$ orang.

Pada siklus II, hasil belajar siswa meningkat menjadi 83,90. Dari 43 orang siswa yang mengikuti tes, siswa yang berkategori amat baik sebanyak 17 $(39,53 \%)$ orang, siswa dengan kategori baik sebanyak $13(30,23 \%)$ orang, siswa dengan kategori cukup sebanyak 12 (27,90\%), dan siswa dengan kategori kurang 1 (2,32\%) orang. Hal ini membuktikan bahwa model pembelajaran ini sudah berhasil diterapkan, karena sudah melebihi $75 \%$. Bedasarkan hasil tindakan tersebut, membuktikan bahwa penerapan model pembelajaran kooperatif tipe STAD pada pembelajaran menulis paragraf eksposisi, sangat efektif untuk digunakan.

\section{PEMBAHASAN}


Pada pembahasan ini, akan diuraikan mengenai temuan dan juga kaitannya denga teori model pembelajaran kooperatif tipe STAD. Pertama, terdapat beberapa langkah dalam penerapan model pembelajaran kooperatif tipe Student Teams Achievement Division (STAD). Model pembelajaran yang sudah diterapkan diatas sudah mendapatkan modifikasi. Akan tetapi, tidak mengurangi dari langkahlangkah pembelajaran kooperatif tipe STAD. Para siswa tersebut diberikan tugas berkelompok untuk membuat paragraf eksposisi dengan tema bebas. Hasil tulisan tersebut akan dipresentasikan di depan kelas. Kemudian dilanjutkan dengan tugas membuat paragraf eksposisi dengan tema bebas tetapi dibuat secara individu.

Kedua, pembelajaran dengan model pembelajaran kooperatif tipe Student Teams Achievement Division(STAD) ini dapat meningkatkan hasil belajar siswa kelas VIII SMP Mutiara Singaraja. Efektifnya model pembelajaran ini, karena model pembelajaran yang diterapkan berbasis dengan kelompok-kelompok kecil, khususnya dapat digunakan pada kelas yang memiliki siswa dengan kemampuan sedang maupun heterogen. Hal ini juga sejalan dengan Rusman (2010:229), bahwa STAD adalah metode yang menyajikan informasi akademik menggunakan presentasi verbal atau teks dan membagi siswa secara heterogen ke dalam kelompok beranggotakan 5-6 orang serta menggunakan prosedur kuis.

Dengan berkelompok siswa akan dapat saling membantu sesama anggota kelompok khususnya dalam menulis paragraf eksposisi. Tidak hanya dalam menentukan tema, tetapi juga dalam mengembangkan tema tersebut. Proses ini akan membantu merangsang otak siswa sebelum menghadapi kuis di akhir pelajaran. Oleh karena itulah, dengan diterapkannya model pembelajaran ini dapat meningkatkan hasil belajar menulis paragraf eksposisi siswa di kelas VIII SMP Mutiara Singaraja.

Sutirman (2013:30) menyatakan bahwa pembelajaran kooperatif yang dilakukan dengan benar akan dapat menimbulkan saling ketergantungan yang positif antar anggota kelompok. Anggota kelompok yang satu membutuhkan anggota kelompok yang lain, sehingga secara otomatis akan terjalin kerjasama yang saling menguntungkan. Sejalan dengan pendapat tersebut, ketika model pembelajaran ini diterapkan di kelas VIII SMP Mutiara Singaraja, kerjasama yang saling menguntungkan terlihat ketika siswa berdiskusi mengenai tema tulisan yang dipilihnya. Dari hal tersebut pula akan terjalin ketergantungan yang positif dan juga tanggung jawab individu terhadap perannya masing-masing. Selain itu, siswa berani melatih kemampuan berbicara mengajarkan sesama teman tidak hanya di depan kelompok, akan tetapi juga di depan kelas. Hal ini juga tanpa disadari, mengajarkan siswa terbuka menerima saran maupun kritik dari teman. Hasil penelitian ini menunjukkan bahwa hasil menulis paragraf eksposisi siswa kelas VIII SMP Mutiara Singaraja meningkat dengan menggunakan model pembelajaran kooperatif tipe Student Teams Teams Achievement Division(STAD).

Selain itu penelitian yang senada dengan penelitian ini, sebelumnya pernah dilakukan oleh Komang Krisna Kumarawati (2015), dengan judul Penerapan Model Pembelajaran Kooperatif Tipe Student Teams Achievement Division (STAD) untuk Meningkatkan Kemampuan Menulis Teks Laporan Hasil Observasi Siswa Kelas X MIA I SMAN 1 Mendoyo". Hasil penelitian ini menggunakan metode tes untuk dapat melihat hasil belajar siswa. Secara kuatitatif, hasil belajar siswa terlihat dari nilai siswa yang meningkat dari siklus I hingga siklus II. Hal ini juga senada dengan Riyanto (2009: 271) menyatakan bahwa pembelajaran kooperatif adalah pembelajaran yang dirancang untuk membelajarkan kecakapan akademik (academic skill), sekaligus keterampilan sosial (social skill) termasuk interpersonal skill.

Oleh karena itulah, dengan digunakannya model pembelajaran ini, tidak hanya dapat meningkatkan keterampilan, kerjasama, dan juga hubungan sosial antar siswa dan guru di dalam kelas saja. Akan tetapi, dengan diterapkannya model pembelajaran ini juga dapat meningkatkan 
kecakapan akademik siswa. Dalam arti, kemampuan kognitif siswa juga menjadi perhatian penting bagi guru, sehingga digunakan model pembelajaran ini, untuk meningkatkan inovasi pembelajaran yang lebih baik lagi.

Peningkatan hasil belajar menulis paragraf eksposisi siswa kelas VIII pada proses pembelajarannya disebabkan oleh model pembelajaran kooperatif tipe Student Teams Achievement Division(STAD) yang sudah dilakukan sesuai dengan langkahlangkah pembelajaran yang ada. Pada saat penerapan model pembelajaran kooperatif Student Teams Achievement Division(STAD)dilakukan dikelas VIII, peneliti membagi siswa menjadi beberapa kelompok secara heterogen. Selanjutnya peneliti meminta siswa untuk mmebuat paragraf eksposisi dengan tema bebas. Selanjutnya, peneliti mengadakan presentasi didepan kelas. Dengan memilih kelompok yang terlebih dahulu menyelesaikan tugasnya Terakhir, peneliti negadakan tes untuk mengetahui hasil belajar siswa.

Model pembelajaran yang sudah diterapkan diatas sudah mendapatkan modifikasi. Akan tetapi, tidak mengurangi dari langkah-langkah pembelajaran kooperatif tipe Student Teams Achievement Division (STAD). Sejalannya hal tersebut, menegaskan bahwa langkah-langkah model pembelajaran kooperatif tipe Student Teams Achievement Division(STAD) ini, dapat dimodifikasi. Semakin baik guru dalam memodifikasi model pembelajaran ini, maka akan semakin baik pula hasil belajar dan semakin sedikit pula permasalahan yang ada di dalam kelas.

\section{SIMPULAN}

1. Penerapan model pembelajaran koopertif tipe Student Teams Achievement Division (STAD) dilihat dari langkahlangkah dalam meningkatkan hasil belajar siswa kelas VIII SMP Mutiara Singaraja, adalah sebagai berikut. Siswa dibagi menjadi beberapa kelompok heterogen. Setiap kelompok menentukan satu tema bebas untuk dikembangkan menjadi paragraf eksposisi. Setelah paragraf eksposisi tersebut dipresentasikan, siswa kembali ke bangku masing-masing. Terakhir, peneliti mengadakan tes untuk mengetahui hasil belajar siswa.

2. Model pembelajaran kooperatif tipe Student Teams Achievement Divison (STAD) dapat meningkatkan kemampuan menulis paragraf eksposisi siswa kelas VIII SMP Mutiara Singaraja. Hal ini dilihat adanya peningkatan kualitas menulis paragraf eksposisi antara refleksi awal, tindakan siklus I dan tindakan siklus II. Pada refleksi awal, hasil yang diperoleh siswa kurang memuaskan, yaitu skor ratarata yang diperoleh sebesar 69,77 . Setelah menerapkan model pembelajaran kooperatif tipe Student Teams Achievement Division (STAD) terjadi peningkatan ratarata sebesar 77,41 pada siklus I, yaitu naik sebanyak 7,64. Peneliti kemudian melakukan tindakan silus II. Pada siklus II, nilai yang diperoleh siswa mencapai ratarata sebesar 83,90. Rata-rata tersebut sudah sangat memenuhi KKM, yakni 76 .

\section{SARAN}

Dalam pembelajaran menulis paragraf eksposisi, guru dapat menerapkan model pembelajaran kooperatif tipe Student Teams Achievement Division (STAD) sebagai alternatif dalam meningkatkan hasil belajar menulis paragraf eksposisi. Model pembelajaran ini dapat memberikan kesempatan berdiskusi yang baik bagi siswa, memberi siswa kesenangan dalam pembelajaran, dan siswa akan lebih aktif dan memahami paragraf eksposisi yang akan dibuat. Model pembelajaran kooperatif tipe Student Teams Achievement Division (STAD) dapat dijadikan pilihan mengajar yang efektif untuk mencapai tujuan pembelajaran yang diharapkan.

Peneliti lain diharapkan melakukan penelitian tindakan lanjutan dengan menerapkan model pembelajaran ini pada aspek keterampilan berbicara. Keterampilan berbicara dan menulis merupakan keterampilan berbahasa yang bersifat produktif. Kedua keterampilan berbahasa ini sangat berhubungan erat dalam pembelajaran bahasa Indonesia.

\section{DAFTAR PUSTAKA}


Alwasilah, A. Chaedar an Suzanna Alwasilah. 2005. Pokoknya Menulis; Cara

Baru Menulis dengan Metode Kolaborasi. Bandung: PT Kiblat BukuUtama.

Ardita, I Nyoman Agus. 2015. Penerapan Model Pembelajaran Kooperatif Tipe STAD (Student Teams Achievement Division) Berbantuan Media Permainan Puzzle untuk Meningkatkan Penguasaan Kosakata Bahasa Jepang pada Siswa Kelas X3 SMK Karya Wisata Singaraja Tahun Ajaran 2014/2015. Skripsi. (tidak diterbitkan). Pendidikan Bahasa Jepang, FBS. Universitas Pendidikan Ganesha.

Balitbang.2002. Kurikulum Berbasis Kompetensi: Kurikulum dan Hasil Belajar (KHB).Jakarta: Bumi Aksara. Jakarta. Kumarawati, Komang Krisna. 2015. Penerapan Model Pembelajaran Kooperatif Tipe Student Teams Achievement Division (STAD) untuk Meningkatkan Kemampuan Menulis Teks Laporan Hasil Observasi Siswa Kelas X MIA 1 SMAN 1 Mendoyo. Skripsi. (tidak diterbitkan). Jurusan Pendidikan Bahasa dan Sastra Indonesia., FBS. Universitas Pendidikan Ganesha.

\section{PendekatanKuantitatif,}

Kuaitatif, dan R\&D. Bandung: Alfabeta.

Tarigan, Henry Guntur. 1986. Menulis sebagai Suatu Keterampilan Berbahasa.Bandung: Angkasa Raya. Tarigan, Henry Guntur. 1994. Menulis sebagai Suatu Keterampilan Berbahasa.Bandung: Angkasa.

Wendra, Wayan. 2014. Penulisan Karya Ilmiah. Jurusan Pendidikan Bahasa dan Sastra Indonesia. Universitas Pendidikan Ganesha.
Puspitawati, Ni ketut Ari. 2013. Penerapan Model Pembelajaran Student Teams Achievement Division (STAD) dengan Media Autentik untuk Meningkatkan Kemampuan Menulis Berita pada Siswa Kelas VIIIB SMP Negrei 1 Kubutambahan. Skripsi. (tidak diterbitkan). Jurusan Pendidikan Bahasa dan Sastra Indonesia, FBS. Universitas Pendidikan Ganesha.

Putra, Putu Edy Permana. 2015. Penerapan Model Pembelajaran Kooperatif Tipe STAD untuk Meningkatkan Kemampuan Siswa Menulis Lengkara dengan Aksara Bali di Kelas X Boga 2 SMK Negeri 1 Seririt Tahun Pelajaran 2014/2015. Skripsi. (tidak diterbitkan). Jurusan Pendidikan Bahasa Bali, FBS. Universitas Pendidikan Ganesha.

Santana K, Septiawan. 2007. Menulis Itu Ibarat Ngomong. Ciganjur. PT KawanPustaka.

Soebachman, Agustina. 2016. Mahir menulis dalam 4 Hari. Yogyakarta. Kauna Pustaka.

Suandi, I Nengah. 2008. Pengantar Metodologi Penelitian Bahasa. Singaraja:Universitas Pendidikan Ganesha.

Suparno. 2002.Menulis Tanpa Rasa Takut Membaca realitas dengan Kritis.Yogyakarta: Kanisius.

Sugiyono. 2007. MetodePenelitianPendidikan:

Widodo, HS. 1994. Pembelajaran keterampilan menulis terpadu. Jakarta: Depdikbud. 